Diana Afrianita, Fitri Eriyantil Kendala Program Jaminan Kecelakaan Kerja pada Badan Penyelenggara Jaminan Sosial Ketenagakerjaan di Kota Padang

Jurnal Manajemen dan llmu Administrasi Dublik (JMIAD)

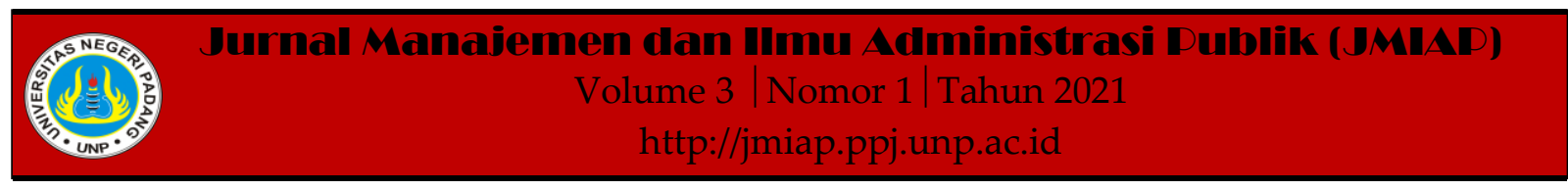

\title{
KENDALA PROGRAM JAMINAN KECELAKAAN KERJA PADA BADAN PENYELENGGARA JAMINAN SOSIAL KETENAGAKERJAAN DI KOTA PADANG
}

\author{
Diana Afrianita ${ }^{1(a)}$, Fitri Eriyanti $^{2(b)}$ \\ ${ }^{1}$ Jurusan Ilmu Administrasi Negara, Universitas Negeri Padang \\ ${ }^{2}$ Jurusan Ilmu Administrasi Negara, Universitas Negeri Padang \\ a)dianaafrianita97@gmail.com, ${ }^{b)}$ fitri.eriyanti@fis.unp.ac.id
}

\begin{abstract}
The research stems from the problem of worker complaints who are members of the Work Accident Security Program. These complaints include the relatively long time for disbursement of guarantees, the cost of recovery is still borne by workers and companies and workers who do not understand the procedures for the Work Accident Security Program at the Manpower Social Security Administration in Padang City. This type of research is qualitative research. This research was conducted at the Office of the Manpower Social Security Administration in the city of Padang. Technique of research informants was purposive. Data collection in this study was carried out by observation, interviews and documentation study. The results of this study indicate that the obstacles to Work Accident Security at the Employment Social Security Administration include long disbursement times, recovery costs are still borne by workers, companies are reluctant to pay medical expenses because they have to wait for confirmation from the Employment Social Security Administration, companies are late in sending. files in the case of work accident reports to the Manpower Social Security Administering Body.
\end{abstract}

Keywords : Effectiveness, constraints, Labor Social Security Administering Bodies

Corresponding author. Email. dianaafrianita97@gmail.com

How to cite this article. Afrianita, D \& Eriyanti, F. (2021). Kendala Program Jaminan Kecelakaan Kerja pada Badan Penyelenggara Jaminan Sosial Ketenagakerjaan di Kota Padang. Jurnal Manajemen dan Ilmu Administrasi Publik (JMIAP) Jurusan Ilmu Administrasi Negara Fakultas Ilmu Sosial Universitas Negeri Padang, Volume 3 (1), Hal. 63-71.

http://jmiap.ppj.unp.ac.id

Copyright@2021. Published by Labor Jurusan Ilmu Administrasi Negara FIS UNP, Padang 


\section{PENDAHULUAN}

Keberadaan Badan Penyelenggara Jaminan Sosial Ketenagakerjaan dan koordinasi Badan Penyelenggara Jaminan Sosial Ketenagakerjaan dengan pihak rumah sakit sudah dilakukan oleh Badan Penyelenggara Jaminan Sosial dan adanya kerjasama dengan seluruh rumah sakit yang ada di Padang, tetapi banyak saja pihak perusahaan yang tidak memasukkan pekerjanya di perusahaan-perusahaan tersebut serta tidak mau mendaftarkan pegawainya untuk menjadi pengguna di Badan Penyelenggara Jaminan Sosial Ketenagakerjaan, alasannya ialah keuntungan pribadi dari Perusahaan tersebut akan berkurang padahal seharusnya Perusahaan tersebut harus menjamin keselamatan karyawan pada saat bekerja dan tidak memikirkan keuntungan pribadinya sendirinya.

Tujuan utama yang dimiliki Badan Penyelenggara Jaminan Sosial Ketenagakerjaan ialah memberi jaminan serta memberi perlindungan sosial untuk pekerja yang ada pada setiap wilayah di Indonesia. Dengan program sebagai perantara, Badan Penyelenggara Jaminan Sosial Ketenagakerjaan berupaya menjamin kejelasan kesejahteraan sosial dan perlindungan bagi pekerja di Indonesia. Munculnya perlindungan sosial danjaminan membuat semua pekerja tidak merasa tidak khawatir dan merasa tenang apabila munculnya kejadian yang tidak di inginkan. Kemungkinan resiko akan terjadi ketika bekerja berupa penyakit, kecelakaan kerja, pemutusan hubungan kerja, pensiunan, kematian akan menjadi lebih mudah apabila seseorang mendaftar diri mereka masing masing menjadi peserta di Badan Penyelenggara Jaminan Sosial Ketenagakerjaan.

Kendala yang dialami oleh pengguna Program Jaminan Kecelakaan Kerja yaitu proses di dalam pengurusan Jaminan Kecelakaan Kerja berbelit-belit dalam pengurusan administrasinya, pengambilan uang santunan lama, kurangnya pelayanan yang diberikan oleh rumah sakit terhadap pekerja atas kasus kecelakaan kerja terjadi di lapangan. Kendala yang dialami di Badan Penyelenggara Jaminan Sosial Ketenagakerjaan diketahui bahwa rata-rata dari pengguna atau perusahaan tidak paham mengenai alur dan prosedur dari program yang ada dan para pengguna belum paham mengenai ketentuan-ketentuan yang mengatur tentang banyak santunan yang akan diterima.

\section{TINJAUAN PUSTAKA \\ Pengertian Efektivitas}

Menurut Steers (Rifa'i, 2013) efektivitas ialah suatu tolak jangkauansebuah program sebagai sistem melalui sarana dan sumber daya tertentu dalammenggapaisasaran dan tujuannya tanpa merusak sumber daya dan cara yang dipakaidan juga tanpa menekankansecara tidak wajar dalam proses pelaksanaannya.

Menurut Hidayat (Publik, 2018) efektivitas yaitu sebuah cara mengukur guna menjelaskan seberapa tinggi target (kualitas, kuantitas dan waktu) yang dicapai. Tingginya efektifitas terjadi apabila terjadinya persentase target yang dicapai membesar.

Hani Handoko (Jibril, 2017) berpendapat efektivitas ialah sebuah relasi antara hasil dengan sasaran, dimana semakin tinggi sebuah efektifitas organisasi, program atau kegiatan jika sumbangan/kontribusi yang dihasilkan lebih tinggi terhadap pencapaian sasaran.

Efektivitas program (dalam Monica, 2017:3) adalah sebuah metode menentukan seberapa besar program yang dijalani dapat terjalani yang bertujuan meraih pencapaian yang telah ditentukan sebelumnya.

(Marina Ayu Prihatmanti, 2013)berpendapat efektivitas program sebagai tahap dari sebuah pencapaian yang diingin diraih dengan cara mengungkapkan seberapa jauh pencapaian program yang telah ditetapkan.

\section{Kendala Efektivitas Program}

Menurut Kusuma \& Djaya (Dian kusuma, 2019) menguraikan dalam 
efektivitas suatu program terdapat beberapa faktor yang mempengaruhinya yaitu antara lain :

1. Kualitas SDM. Pada dasarnya kualitas sumber daya manusia ialah tingkatan pengetahuan keahlian dan keinginanyang beradadalam sumber daya manusia. Berdasarkan hal tersebut kualitas merupakan sesuatu yang dapat disempurnakan.

2. Kompetensi Administrator. Kompetensi atau kemampuan adalah kapasitas seseorang dalam mengurus segala pekerjaan. Yang membedakan antara kemampuan fisik dengan kemampuan intelektual: a) Kemampuan fisik ialah kemampuan dalam melaksanakan sebuah urusan yang dirasa kurang sesuai dengan keterampilannya contohnya pekerjaan yang tingkat keberhasilannya mewajibkan stamina ketanggapan fisik sebagai ketahanan atau bisa jadi talenta yang hampir sama dengan manajemen untuk memadai keterampilan fisik seorang pekerja. B) Kemampuan intelektual ialah kemampuan wajib dimiliki masing masing individu yang didasari dengan tingkat pendidikan formal atau pendidikan kedinasan semacamnya. Dari hal tersebut diketahui bahwa kemampuan fisik berhubungan dengan keterampilan kerja atau skill seseorang, sedangkan kemampuan intelektual lebih mengarah pada tingkat pengetahuan dan pendidikan individu.

3. Sarana prasarana. Sarana sebagai pendukung atau peralatan kerja, biasa dikatakan termasuk dalam artian sarana sedangkan prasarana ialah hal urgensi dalam pengurusan proses suatu program. Adapun pada sarana dan prasarana memiliki beberapa faktor berupa perlengkapan dalam terselenggaranya aktivitas pemerintah guna memperlancar atau mempermudah pergerakan aktivitas yang dilakukan pemerintah.

4. Pengawasan. Pengawasan ialah satu dari beberapa fungsi manajemen yang menjadi jalannya proses aktivitas pemimpin dalam menjamin dan memastikan terlaksananya sasaran dan tugas di suatu lembaga dengan benar selama selaras dengan ketentuanketentuan dan kebijakan pedoman rencana yang telah ditetapkan(Manullang $\mathrm{M}$, 2001)mengatakan pengawasan ialah proses penetapan pekerjaan yang telah dirasa penilaiannya sudah baik dan serta koreksi yang benar dengan tujuan agar dalam bekerja telah sesuai rencana yang sudah ada.

Edward III (dalam (Arinda et al., n.d.) menguraikan keberhasilan atau kegagalannya suatu program terdapat empat faktor yang memiliki pengaruh, dan empat faktor atau variabel yang dikatakan tersebut antara lain:

1. Komunikasi. Komunikasi ialah proses dalam menyampaikan informasi keputusan dari orang yang membuatkeputusanterhadap pelaksana kebijakan. Pada komunikasi terdapat dimensi dimensi yakni dimensi konsistensi dan transformasi kejelasan.

2. Sumber daya. Sumber energi selaku energi dukung dalam penerapan sesuatu keputusan yang terdiri dari sumber energi manusia, sumber energi perlengkapan serta sumber energi anggaran. Sumber energi manusia ialah satu dari sebagian variabel yang mempengaruhi pada keberhasilan ataupun kegagalan terlaksananya keputusan. Sebaliknya sumber energi perlengkapan yakni fasilitas yang dipakai buat mengoperasikan aktivitas sesuatu keputusan. Tetapi apabila sumber energi anggaran terbatas hingga bisa berikan akibat pada mutu pelayanan publik.

3. Disposisi. Disposisi ialah kecenderungan dan keinginan para pelaku kebijakan untuk mengimplementasikankeputusandenga $\mathrm{n}$ bersungguh sungguh sehingga tujuan kebijakan yang diinginkan dapat diwujudkan. 
4. Struktur birokrasi. Cakupan pada struktur birokrasi ialah aspek yang berupa struktur organisasi pemisahanotoritasrelasi antara masing masing unit di dalam organisasi yang bersangkutan sertarelasi organisasi tertentu bersama organisasi luar.

\section{Indikator Efektivitas}

Menurut Subagyo dan Mubyarto(BudianiBudiani. (2007). Efektivitas Program Penanggulangan pangangguran Karang Taruna Eka Taruna Bhakti. 2, 2007)efektivitas suatu program dapat diukur keberhasilan atau tidaknya melalui indikator sebagai berikut:

1. Ketepatan Sasaran Program. Ketepatan sasaran program ialah ukuran seberapa jauh peserta program mencapai sasaran yang sudah ditetapkan oleh penyelenggara program sebelumnya. Ketepatan sasaran program lebih mengarah ke waktu jangka pendek dan lebih bersifat operasional di mana ketepatan sasaran program ini sangat berpengaruh terhadap pencapaian tujuan program agar sesuai dengan tujuan yang ditetapkan maka dalam penentuan sasaran program harus sesuai dengan kriteria-kriteria penerima manfaat dari program tersebut.

2. Sosialisasi Program. Sosialisasi program merupakan keahlian dari seseorang dalam menyelenggarakan program ketika pelaksanaan sosialisasi sehingga informasi tentang terselenggaranya program bisa tersampaikan ke masyarakat terutama mengenai sasaran program ini. Tersampainya informasi menjadi langkah awal yang dilaksanakan supaya mendapatkan hasil yang maksimal pada sebuah program karena tersampainya informasi tentang program tersebut mampu mengembangkan ilmu pengetahuan kepada penerima informasi tersebut. Pada aspek ini,cara mengukur keberhasilan sosialisasi menggunakan tiga indikator yakni antara lain: a. Transmisi sosialisasi, yakni diperlukannyaupaya program dan keputusan yang dibuat dapat dimodifikasikepada semua pelaksana baik itu kelompok ataupun pihak individu yang berkaitan dengan sasaran, program dan keputusan yang telah ditetapkan.

b. Kejelasan, yakni memerlukan sebuah pelaksanansosialisasi program dimana kegiatan tersebut harus mudah dipahamisupayakedepannyakegiat antersebutcocok dengan maksud ingin disampaikan.

c. Konsistensi, yakni dibutuhkannya pengaplikasiandarisebuah program tertentu

yangmestiselarassertamudahdipaha misupaya terlaksananya keefektifan programdan kebijakan yang yang telah ditetapkan.

3. Tujuan Program. Tujuan program disusun guna memperjelas pencapaian sasaran program yang ingin diraih dan untuk melihat seberapa jauh selarasnya hasil kegiatan program yang telah dilaksanakan dengan sasaran program yang telah diputuskan oleh penyelenggara program sebelumnya. Ada beberapa karakteristik dalam mencapai sebuah sasaran program yakni antara lain:

a. Kecendrunganprogrammemerluk anpegawaiseperti sebagai pelaku program ketikadalampengaplikasian.

b. Umumnya program biasanya mempunyaidanacadangan tersendiri yang kegunaannya untuk penyelenggaraan program ketika diperlukan pada waktunya.

c. Program sendiri mempunyai ciri tersendiri dimana masing masing ciri ciri tersebut akan bermanfaat apabila beroperasidenganefektif serta adanya pengakuan dari publik. 
Diana Afrianita, Fitri Eriyantil Kendala Program Jaminan Kecelakaan Kerja pada Badan Penyelenggara Jaminan Sosial Ketenagakerjaan di Kota Padang

4. Pemantauan Program. Pemantauan program ialah suatu aktivitas yang dicoba sehabis dilaksanakannya sesuatu program yang mana hal ini menjadi sebuah gambaran ketertarikan dari seorang peserta pengguna program. Pemantauan juga bisa dianggap sebagai aktivitas dari mengamati berkembangnya suatu penyelenggaraan rencana atau bisa dikatakan sebagai suatu perencanaan yang meliputi identifikasi serta antispasi terhadap munculnya permasalahan atau antispasi dengan hal yang lainnya guna mengambil tindakan secepat mungkin. Pada aspek ini, pemantauan memiliki beberapa tujuan guna keberhasilan suatu efektivitas yakni antara lain:

a. Mempelajari kembali secara mendalam tentang kegiatan dari pelaksanaan sebuah keputusan atau program tersebut apakah terlaksana dengan baik dan tepat pada sasaran yang telah ditetapkan.

b. Mengidentifikasi permasalahan yang munculsehingga bisa langsung diatasi dengan benar.

c. Menilai atau mengukur tentangbagaimana pola kerja serta penggunaan manajemen telah selaras dengankeputusan yang telah ditetapkan guna tercapainya sebuahsasaran program.

d. Memahamihubungan yang terjadi antara sebuah penyelenggaraan kegiatan dengan sasarandalammendapatkan sebuah ukuran yang dapatmemajukan program.

e. Menyelaraskan antarasebuahpenyelenggaraankeg iatan dengan lingkungan selalu terjadi perubahan tanpa menganggu dari sasaran yang telah diketahui.
Badan Penyelenggara Jaminan Sosial Ketenagakerjaan

1. Pengertian Badan Penyelenggara Jaminan Sosial Ketenagakerjaan. Menurut Peraturan Menteri Ketenagakerjaan Republik Indonesia Nomor 35 Tahun 2016 Tentang Tata Cara Pemberian, Persyaratan, dan Jenis Manfaat Layanan Tambahan dalam Program Jaminan Hari Tua, Badan Penyelenggara Jaminan Sosial Ketenagakerjaan yang selanjutnya disebut dengan BPJS Ketenagakerjaan dapat diartikan sebagai sebuah badan hukum publik yang didirikansesuai Undang-Undang Nomor 24 Tahun 2011 tentang Badan Penyelenggara Jaminan Sosial.

2. Pembentukan dan Ruang Lingkup BPJS Ketenagakerjaan. (Presiden Republik Indonesia, 2011) Menurut pasal 5 ayat 2 Undang-Undang Nomor 24 Tahun 2011, dapat diambil kesimpulan bahwa ruang lingkup dan pembentukan dari BPJS yakni BPJS Kesehatan dan BPJS Ketenagakerjaan.

3. Menurut pasal 6 ayat 2 Undang-Undang Nomor 24 Tahun 2011 tentang Ruang Lingkup BPJS Ketenagakerjaan, terdapat beberapa ruang lingkupnya yaitu aJaminan Kecelakaan Kerja, Jaminan Pensiun, Jaminan Hari Tua, dan Jaminan Kematian.

\section{Program Jaminan Kecelakaan Kerja}

Penafsiran Jaminan Musibah Kerja ada pada Peraturan Menteri Ketenagakerjaan Republik Indonesia No 1 Tahun 2016 Tentang Tata Metode Penyelenggaraan Program Jaminan Musibah Kerja, Jaminan Kematian serta Jaminan Hari Tua untuk Partisipan Bukan Penerima Upah, pada bab 1 pasal 1 ayat 1 yang bisa diambil kesimpulan bahwa Jaminan Kecelakaan Kerja (JKK) ialah sebuah pengambilan manfaat berbentuk uang secara tunai ataupun berupa pelayanan kesehatan yang diberi ketika pengguna program mengalami sebuah penyakit atau kecelakaan kerja yang diakibatkan oleh lingkungan dimana 
mereka bekerja. Sedangkan maksud dari kecelakaan kerja, pengertiannya tercantum pada pasal 1 ayat 6 yang dapat disimpulkan sebagai kecelakaan yang berlangsung dengan yang berhubungan dengan lingkungan mereka bekerja, termasuk musibah yang terdapat dalam ekspedisi pengguna dari rumah mereka mengarah tempat mereka bekerja, serta pula penyakit yang disebabkan area kerja.

1. Tata cara pendaftaran kepesertaan.

Bagi Bab II pasal 2 Peraturan Menteri Ketenagakerjaan No 1 Tahun 2016 Tata Metode Registrasi Kepesertaan( JKK) BPJS Ketenagakerjaan merupakan selaku berikut:

a. Pengguna merupakan orang yang menerima upah, maka harus mendaftarkan diri kepada BPJS Ketenagakerjaan sesuai prosedur kepesertaan.

b. Dalam melakukan pendaftaran, peserta sendiri yang harus melakukannya tanpa menggunakan perantara atau sekelompok tertentu yang dibuat oleh peserta.

c. Pendaftaran dilakukan sendiri langsung oleh peserta melewati kantor cabang BPJS Ketenagakerjaan atau Kanal pelayanan BPJS Ketenagakerjaan.

d. Pendaftaran juga dapata dilakukan menggunakan perantara atau skelompok tertentu yang telah dibetuk melewati kantor cabang BPJS Ketenagakerjaan.

e. Dalam mendaftar, harus diperlukan langkah pengisian formulir pendaftaran yang sudah diputuskan oleh BPJS Ketenagakerjaan.

f. Dalam pendaftaran pelaksanaannya dikerjakan dengan cara manual atau bisa juga menggunakan media/alat elektronik.

g. Manfaat Jaminan Ketenagakerjaan BPJS Ketenagakerjaan (Kemnaker No. 1 Tahun 2016.pdf, n.d.) Menurut pasal 16 ayat 2 Peraturan Menteri Ketenagakerjaan Nomor 1 Tahun 2016 manfaat Jaminan Kecelakaan Kerja BPJS
Ketenagakerjaan dapat diambil kesimpulan tersendiri yaitu :

1) Pada aspek pelayanan kesehatan disesuaikan dengan kebutuhan di bidang medis yakni:

- Pemeriksaan dasar dan penunjang

- Jasa dokter/ medis

- Pengobatan

- Perawatan tingkat pertama dan lanjutan

- Penunjang diagnostik

- Alat kesehatan dan implant

- Terdapatnya rawat inap kelas 1 di tiap rumah sakit baik itu rumah sakit pemerintah pusata, rumah sakit pemerintah wilayah maupun rumah sakit swasta.

- Pelayanan khusus

- Transfusi darah

- Perawatan intensif

- Operasi

- Rehabilitasi medik.

2) Dalam aspek santunan biasanya berupa uang tunai dengan memiliki salah satu dari beberapa kriteria sebagai berikut:

- Biaya ganti bagi pengguna program jika yang mengalami kecelakaan kerja, ataupun menderita penyakit ketika bekerja ke rumah sakit atau bisa langsung ke rumah si pengguna program dan juga termasuk biaya pada pertolongan pertama ketika kecelakaan terjadi.

- Santunan sementara dikarenakan tidak dapat bekerja untuk beberapa hari kedepan.

- Santunan terjadinya kecacatan sebagian anatomi, kecacatan sebagian fungsi, atau bisa 
Diana Afrianita, Fitri Eriyantil Kendala Program Jaminan Kecelakaan Kerja pada Badan Penyelenggara Jaminan Sosial Ketenagakerjaan di Kota Padang

jadi terjadi kecacatan total tetap.

- Santunan akibat kematian beserta dengan uang pengeluaran pemakaman.

- Santunan berkala yang dikeluarkan sekalian jika pengguna program hadapi kematian ataupun wafat dunia ataupun kecacatan total senantiasa yang disebabkan musibah kerja ataupun penyakit dirasakan kala bekerja.

- Bayaran kala rehabilitasi berupa penukaran perlengkapan bantu( orthose) serta perlengkapan pengganti( prothese).

- Bayaran ubah rugi terhadap gigi tiruan

- Diberikannya beasiswa pendidikan kepada anak yang dimana pengguna program tersebut meninggal dunia atau penyakit dialami ketika be kerja.

- Jumlah beasiswa pendidikan yang diberikan kepada anak tersebut adalah sebesar Rp 12.000.000,00 (dua belas juta rupiah) bagi setiap pengguna program yang mempunyai anak berdasarkan ketentuan peraturan perundangundangan.

Keterkaitan Jaminan Kecelakaan Kerja dengan Badan Penyelenggara Jaminan Sosial Ketenagakerjaan

Berdasarkan pasal 6 ayat 2 huruf $b$ Undang -Undang Nomor 24 Tahun 2011 diketahui bahwa BPJS Ketenagakerjaan ruang lingkupnya meliputi program jaminan kecelakaan kerja. Hal ini berarti jika terjadi kecelakaan kerja maka BPJS Ketenagakerjaan berkewajiban memberikan jaminan kepada tenaga kerja yang mengalami kecelakaan kerja sesuai ketentuan peraturan perundang-undangan yang berlaku.

\section{METODE PENELITIAN}

Metode yang dipakai ialah metode kualitatif. Tempat pelaksanaannya penelitian ini di kantor Badan Penyelenggara Jaminan Sosial Ketenagakerjaan di Kota Padang.peneltian ini meneliti tentang kendala dari Program Jaminan Kecelakaan Kerja Pada Badan Penyelenggara Jaminan Sosial Ketenagakerjaan di Kota Padang.Metode dalam mengambil data peneltian ini adalah dengan dilakukan dengan menggunakan langakah observasi, wawancara serta studi dokumentasi. Sedangkan dalampengujian keabsahan data dengan cara triangulasi. Penelitian ini dilakukan dengan teknik Reduksi Data, Penyajian data, Penarikan kesimpulan.

\section{HASIL DAN PEMBAHASAN \\ Kendala dalam efektivitas Program Jaminan Kecelakaan Kerja Di Badan Penyelenggara Jaminan Sosial Ketenagakerjaan Kota Padang}

Edward III (dalam Arinda Suryadi \&Adiono 2014) menguraikan keberhasilan atau kegagalannya suatu program terdapat empat faktor yang memiliki pengaruh, dan empat faktor atau variabel yang dikatakan tersebut antara lain:

1. Komunikasi. Komunikasi ialah proses dalam menyampaikan informasi keputusan dari orang yang membuat keputusan terhadap pelaksana kebijakan. Pada komunikasi terdapat dimensi dimensi yakni dimensi konsistensi dan transformasi kejelasan.

2. Sumber daya. Sumber daya sebagai daya dukung dalam pelaksanaan suatu keputusan yang terdiri dari sumber daya manusia, sumber daya peralatan dan sumber daya anggaran.Sumber daya manusia merupakan satu dari beberapa variabel yang berpengaruh pada keberhasilan atau kegagalan terlaksananya keputusan.Sedangkan sumber daya peralatan ialah sarana yang 
dipakai untuk mengoperasikan kegiatan suatu keputusan.Namun apabila sumber daya anggaran terbatas maka dapat memberi dampak pada kualitas pelayanan publik.

3. Disposisi. Disposisi ialah kecenderungan dan keinginan para pelaku kebijakan untuk mengimplementasikankeputusandenga $\mathrm{n}$ bersungguh sungguh sehingga tujuan kebijakan yang di idamkan bisa diwujudkan.

4. Struktur birokrasi. Cakupan pada struktur birokrasi ialah aspek yang berupa struktur organisasi pemisahanotoritasrelasi antara masing masing unit di dalam organisasi yang bersangkutan sertarelasi organisasi tertentu bersama organisasi luar.

Ada pula hambatan daya guna Program Jaminan Musibah Kerja di Tubuh Penyelenggara Jaminan Sosial Ketenagakerjaan di Kota Padang merupakan selaku berikut:

1. Waktu pencairan jaminan relatif lama. Penyebab dari waktu pencairan yang lama karena pihak Badan Penyelenggara Jaminan Sosial Ketenagakerjaan memantau terlebih dahulu apakah benar kasus kecelakaan kerja itu terjadi.

2. Biaya pemulihan masih ditanggung oleh pekerja. Karena dalam ketentuan Badan Penyelenggara Jaminan Sosial Ketenagakerjaan tidak hanya biaya rumah sakit yang ditanggung tetapi juga biaya pemulihan.

3. Perusahaan telambat dalam mengirim berkas atas kasus kecelakaan kerja di Badan Penyelenggara Jaminan Sosial Ketenagakerjaan di Kota Padang. Penyebab keterlambatan perusahaan dalam mengirim berkas adalah karena perusahaan harus menanggung biaya sementara dari kasus kecelakaan kerja yang terjadi akibat yang dirasakan pekerja.

4. Industri enggan membayarkan bayaran penyembuhan sebab bayaran penyembuhan sebab wajib menunggu konfirmasi dari Tubuh Penyelenggara Jaminan Sosial Ketenagakerjaan. Proses mengklaim duit jaminan musibah kerja relatif lama, sebab pihak Tubuh Penyelenggara Jaminan Sosial Ketenagakerjaan wajib membenarkan terlebih dulu hendak kebenaran permasalahan yang terjalin.

\section{PENUTUP}

Berdasarkan hasil penelitian yang dikerjakan di lapangan serta telah dijelaskan sebelumnya makadiambil kesimpulan bahwa terdapat beberapa kendala dalam efektivitas Program Jaminan Kecelakaan Kerja di Badan Penyelenggara Jaminan Sosial Ketenagakerjaan di Kota Padang:

1. Waktu pencairan jaminan relatif lama. Penyebab dari waktu pencairan yang lama karena pihak Badan Penyelenggara Jaminan Sosial Ketenagakerjaan memantau terlebih dahulu apakah benar kasus kecelakaan kerja itu terjadi.

2. Biaya pemulihan masih ditanggung oleh pekerja. Karena dalam ketentuan Badan Penyelenggara Jaminan Sosial Ketenagakerjaan tidak hanya biaya rumah sakit yang ditanggung tetapi juga biaya pemulihan.

3. Perusahaan terlambat dalam mengirim berkas atas kasus kecelakaan kerja di Badan Penyelenggara Jaminan Sosial Ketenagakerjaan di Kota Padang. Penyebab keterlambatan perusahaan dalam mengirim berkas adalah karena perusahaan harus menanggung biaya sementara dari kasus kecelakaan kerja yang terjadi akibat yang dirasakan pekerja.

4. Industri enggan membayarkan bayaran penyembuhan sebab bayaran penyembuhan sebab wajib menunggu konfirmasi dari Tubuh Penyelenggara Jaminan Sosial Ketenagakerjaan. Proses mengklaim duit jaminan musibah kerja relatif lama, sebab pihak Tubuh Penyelenggara Jaminan Sosial Ketenagakerjaan wajib 
Diana Afrianita, Fitri Eriyantil Kendala Program Jaminan Kecelakaan Kerja pada Badan Penyelenggara Jaminan Sosial Ketenagakerjaan di Kota Padang

membenarkan terlebih dulu hendak kebenaran permasalahan yang terjalin.

\section{DAFTAR KEPUSTAKAAN}

Arinda, P. R., Adiono, R., Publik, J. A., Administrasi, F. I., \& Brawijaya, U. (n.d.). Efektivitas Penerapan B-Diso ( Banyuwangi Digital Society) Dalam Meningkatkan Mutu Pelayanan Bidang Pendidikan ( Studi pada Dinas Pendidikan Kabupaten Banyuwangi ). 2(2), 360-366.

BudianiBudiani. (2007). Efektivitas Program Penanggulangan pangangguran Karang Taruna Eka Taruna Bhakti. 2, 9-57. (2007). Efektivitas Program Penanggulangan pangangguran Karang Taruna Eka Taruna Bhakti. 2, 9-57.

Dian kusuma, dkk. (2019). Efektivitas Pelaksanaan Peraturan Bupati Nomor 24 Tahun 2016 Tentang Program Bantuan Pendidikan.

Jibril, A. (2017). Efektivitas Program Perpuseru Di Perpustakan Umum Kabupaten Pamekasan. 6(2).

Kemnaker No. 1 Tahun 2016.pdf. (n.d.).

Manullang M. (2001). Dasar Dasar Manajemen. Sinar Harapan.

Marina Ayu Prihatmanti. (2013). Efektivitas Program Kesejahteraan Sosial Anak Balita (PKSAB) Di Tas Dr. Soetomo Surabaya. Kebijakan Dan Manajemen Publik, 1.

Presiden Republik Indonesia. (2011). Badan Penyelenggara Jaminan Sosial.

Publik, P. (2018). Efektivitas Program Cerdas Command Center Sebagai Media Informasi Masyarakat Dalam Rangka Pelayanan Publik (Studi di Kantor Walikota Manado). 1(1).
Rifa'i, B. (2013). Efektivitas Pemberdayaan Usaha Mikro Kecil dan Menengah (UMKM) Krupuk Ikan dalam Program Pengembangan Labsite Pemberdayaan Masyarakat Desa Kedung Rejo Kecamatan Jabon Kabupaten Sidoarjo. Journal Unair, 1(1), 1-7. 